\title{
REDUCING ENERGY CONSUMPTION BY PASSENGER CAR WITH USING OF NON-ELECTRICAL HYBRID DRIVE TECHNOLOGY
}

\author{
Tomas Skrucany', Veronika Harantova', Martin Kendra', Dalibor Barta ${ }^{2}$ \\ 1 University of Zilina, Faculty of Operation and Economics of Transport and Communications, Univerzitna 1, \\ 01026 Zilina, Slovak Republic, e-mail: tomas.skrucany@fpedas.uniza.sk, harantova3@stud.uniza.sk, martin. \\ kendra@fpedas.uniza.sk \\ 2 University of Zilina, Faculty of Mechanical Engineering, Univerzitna 1, 01026 Zilina, Slovak Republic, e-mail: \\ dalibor.barta@fstroj.uniza.sk
}

Received: 2016.12 .15

Accepted: 2017.02.01

Published: 2017.03.01

\begin{abstract}
Not only electrical hybrid technology is used for drivetrain of passenger cars. Also other systems using non-electrical principles (hydraulic or air pressure, mechanical energy storage) can be found in modern vehicles. There is a quantification of the spared energy by using a hybrid vehicle in the paper. Driving cycle ECE 15 was chosen as a platform for simulation of driving resistances.
\end{abstract}

Keywords: non-electrical hybrid technology, transport energy intensity, driving resistances, energy storage.

\section{INTRODUCTION}

Energy intensity of transport is a current topic around the world. All sites of transport service are trying to improve vehicle fuel consumption, which is the biggest part of the energy consumption in transport. Hybrid vehicles are the last direction in this area. Hybrid vehicles are vehicles equipped mostly with petrol-electric engines, which are used for recuperation of the vehicle kinetic energy during breaking phases of driving. But not only electric hybrid vehicles are used. This paper deals with the calculation of energy savings using nonelectric hybrid drive technology in cars.

\section{HYBRID AIR}

The system is presented in two concepts, Citroën C3 and Peugeot 2008. Hybrid Air system of drive module combines air, hydraulics and fuel.

It uses compressed air (actually pure nitrogen) and a hydraulic motor instead of electricity, supporting the combustion engine. It theoretically gives the same benefits for fuel consumption as it is at a conventional hybrid.

\section{OPERATION PRINCIPLE OF THE HYBRID AIR SYSTEM}

Hybrid Air system combines two energy to achieve maximum performance depending on various situations. Compressed air helps gasoline engine or supplies it. Together they contribute to the most efficient operations in transient phases during the acceleration and starting.

Three-cylinder spark-ignition engine delivers more power through a planetary gearbox that controls the distribution of both of the used energy sources. In this case the noise and vibration are problems but, on the other hand, they can be used in condition monitoring [14, 15]. Engine weight is up to $21 \mathrm{~kg}$ lower, compared to the current three-cylinder engine. Planetary gearbox supplies mechanical gearbox and it offers better automation in the gearshift. The pump and hydraulic motor powered by compressed air take the role of the electric motor.

The charging of the high-pressure tank proceeds in two ways. The deceleration is not done by using of brake pads pressure on the disc during the deceleration (braking or releasing the accelerator pedal) but by the resistance to compression 


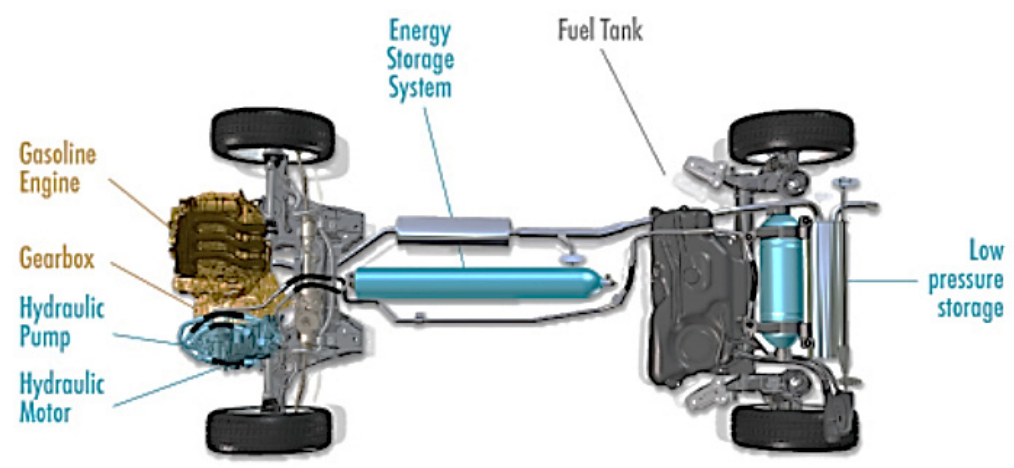

Fig. 1. Diagram and description of Hybrid Air system components [2]

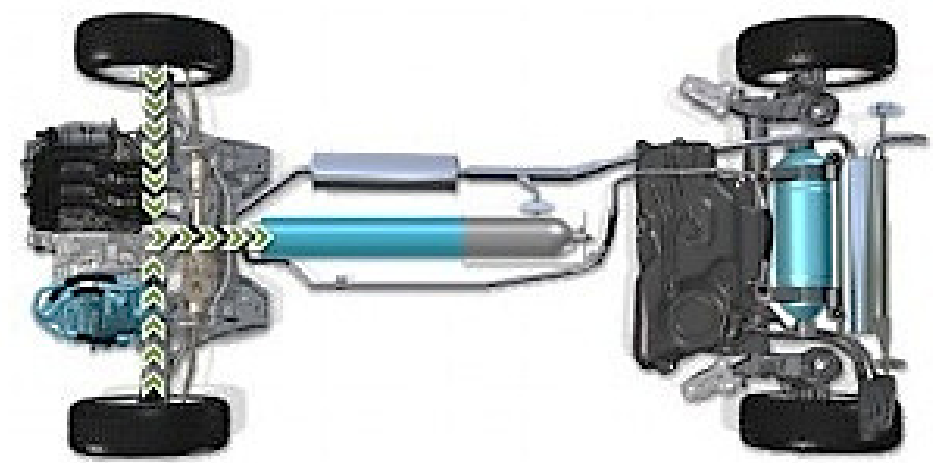

Fig. 2. The air compression into the high-pressure tank [2]

of air in this tank. The second alternative is to recharge it by the starting of the gasoline engine. The part of the energy obtained from the gasoline engine is used to compress air in this situation. In both alternatives, maximum energy capacity of the high-pressure tank is very quickly achieved, i.e. within ten seconds. This energy is re-used during the starting or overtaking.

During the deceleration, the wheels energy actuates the hydraulic pump that pushes hydraulic fluid into the high pressure tank and compresses the air inside the tank (Figure 2). If the vehicle needs to speed up, the system works in reverse. Compressed air pushes the hydraulic fluid that actuates the hydraulic motor connected to the planetary gearbox.

\section{CALCULATION OF THE VEHICLE KINETIC ENERGY}

The vehicles Citroen C3 and Citroen C3 Hybrid Air were used in calculations. The calculations refers to the urban driving cycle ECE 15. The most often used tire size for vehicle Citroën $\mathrm{C} 3$ is $175 / 65 \mathrm{R} 14$.

Table 1. Parameters required to the calculation of the vehicle Citroën C3 kinetic energy

\begin{tabular}{|c|c|c|c|}
\hline Vehicle curb weight & $1140 \mathrm{~kg}$ & Rotating masses coefficient $(\delta)$ & $1,1[1]$ \\
\hline Vehicle actual weight by $(\mathrm{m})$ & 1340 kg [1] & Overall transmission efficiency estimating ${ }^{1}$ & 0,93 \\
\hline Aerodynamic drag coefficient $\left(c_{x}\right)$ & 0,307 & Rolling resist. coefficient (f) & $0,011[1]$ \\
\hline Frontal area $(\mathrm{S})$ & $2,11 \mathrm{~m}^{2}$ & \multirow{3}{*}{ Vehicle acceleration (a) } & $1,043 \mathrm{~m} \cdot \mathrm{s}^{-2}$ \\
\hline Gravity acceleration (g) & $9,81 \mathrm{~ms}^{-2}$ & & $0,741 \mathrm{~m} \cdot \mathrm{s}^{-2}$ \\
\hline Air density $(\rho)$ & $1,29 \mathrm{~kg} \cdot \mathrm{m}^{-3}$ & & $0,534 \mathrm{~m} \cdot \mathrm{s}^{-2}$ \\
\hline \multirow{4}{*}{ Vehicle speed (v) } & $4,17 \mathrm{~m} \cdot \mathrm{s}^{-1}$ & \multirow{4}{*}{ Vehicle deceleration $(b,-a)$} & $0,834 \mathrm{~m} \cdot \mathrm{s}^{-2}$ \\
\hline & $8,89 \mathrm{~m} \cdot \mathrm{s}^{-1}$ & & $0,808 \mathrm{~m} \cdot \mathrm{s}^{-2}$ \\
\hline & $13,89 \mathrm{~m} \cdot \mathrm{s}^{-1}$ & & $0,521 \mathrm{~m} \cdot \mathrm{s}^{-2}$ \\
\hline & $9,73 m \cdot s^{-1}$ & & $0,811 \mathrm{~m} \cdot \mathrm{s}^{-2}$ \\
\hline
\end{tabular}




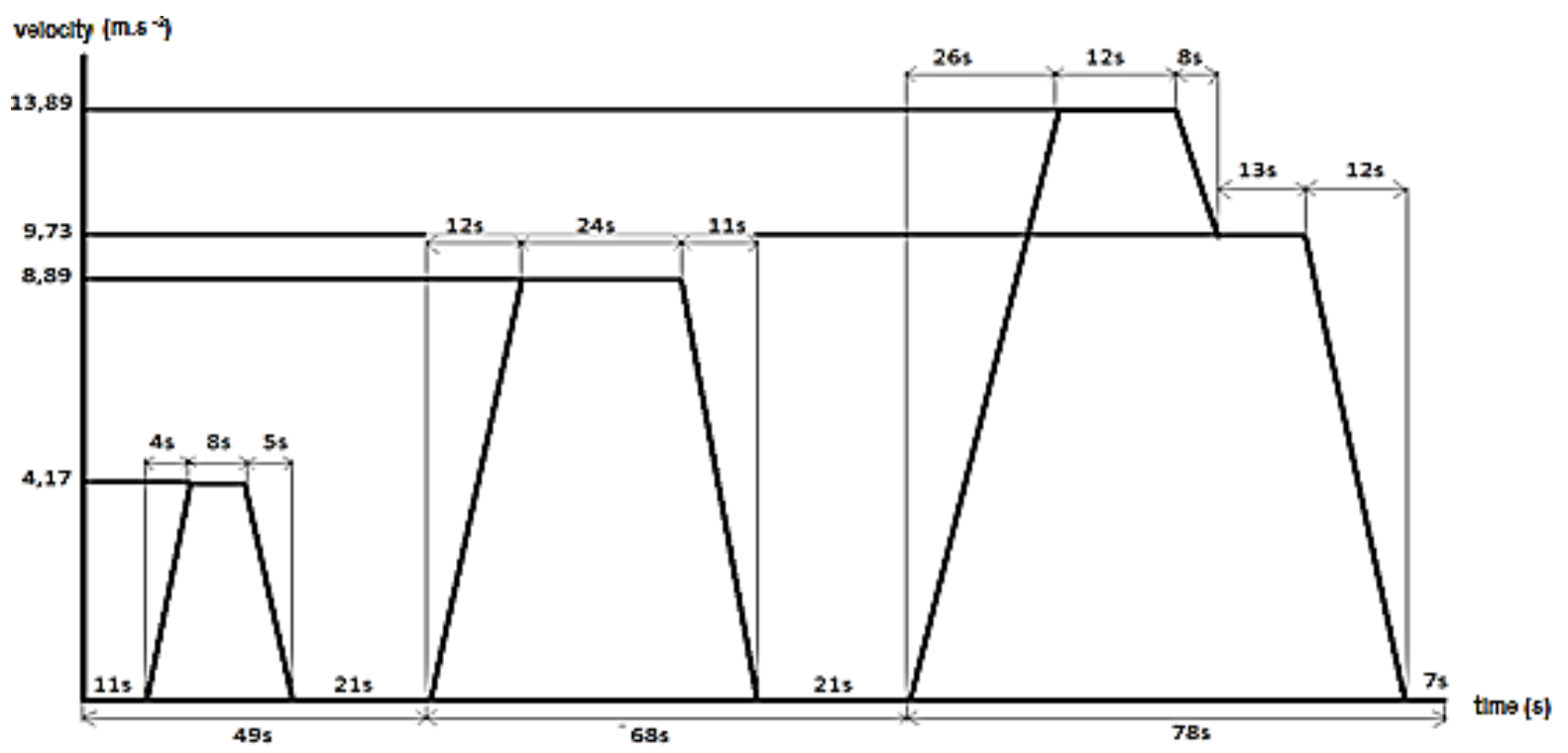

Fig. 3. Driving cycle ECE 15 divided into partial periods and 3 phases

The parameters needed to calculate the kinetic energy of Citroën C3 Hybrid Air vehicle are the same. The only difference is in the weight and size of the tire. In the calculation the same values of parameters except of the weight and rolling resistance coefficient were considered. The weight of the Hybrid Air system is about $100 \mathrm{~kg}$ higher than the common Citroën $\mathrm{C} 3$ and tires size is $165 / 50 \mathrm{R} 18$. They have a smaller value of the rolling resistance coefficient, with an estimation of about $0,008[3,4,7,9]$.

\section{CALCULATION OF THE DRIVING RESISTANCE AND ENERGY}

To calculate the total energy, first it is necessary to calculate the forces needed to overcome the driving resistances that act on the vehicle and the energy required for acceleration of the vehicle, steady vehicle driving and braking of the vehicle $[12,13]$.

Phase 1 has duration $49 \mathrm{~s}$, where acceleration time is equal $4 \mathrm{~s}$ and has value $1,043 \mathrm{~m} \cdot \mathrm{s}^{-2}$, stage of constant speed continues 8 s with value 4,17 $\mathrm{m} . \mathrm{s}^{-1}$ and deceleration stage is equal $5 \mathrm{~s}$ with value $0,834 \mathrm{~m} \cdot \mathrm{s}^{-2}$.

Equations of the vehicle driving resistances have been used for calculation all resistances with inputs from the Table 1.

- Air resistance

$$
O_{v}=\frac{1}{2} \cdot \rho \cdot S \cdot c_{x} \cdot v^{2}
$$

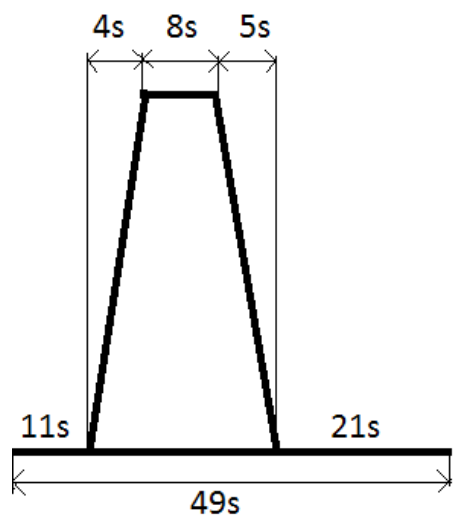

Fig. 4. First phase of driving cycle ECE 15

- Rolling resistance

$$
o_{f}=f \cdot G \cdot \cos \alpha=f \cdot m \cdot g \cdot \cos \alpha
$$

- Inertia resistance

$$
o_{a}=a \cdot m \cdot \delta
$$

- Vehicle acceleration

Distance necessary for the vehicle acceleration:

$$
s=\frac{t^{2} \cdot a}{2}=\frac{v^{2}}{2 \cdot a}=\frac{4,17^{2}}{2 \cdot 1,043}=8,34 m
$$

Energy calculation was done as multiple of the driven distance and driving resistance, for example: energy to overcome rolling resistance:

$$
E_{f}=s . O_{f}
$$

The total energy $E_{\mathrm{T}}$ in acceleration process is summary of energy consumption in all modes: 


$$
E_{T}=E_{f}+E_{v} \pm E_{a}=1205,96+15,18+12821,77=14132,91 \mathrm{~J}
$$

Constant speed of the vehicle

Distance with a constant speed of the vehicle:

$$
s=v \cdot t=4,17.8=33,36 \mathrm{~m}
$$

Energy needed for the constant speed:

$$
E_{C V}=\left(O_{v}+O_{f}\right) \cdot s
$$

Deceleration of the vehicle

Distance needed for the vehicle deceleration:

$$
s=\frac{t^{2} \cdot b}{2}=\frac{v^{2}}{2 . b}=\frac{4,17^{2}}{2.0,834}=10,43 \mathrm{~m}
$$

Total energy during the deceleration:

$$
E_{T}=E_{f}+E_{v} \pm E_{a}=1508,18+18,98-12815,62=-11288,46 J
$$

All calculated results for Citroën $\mathrm{C} 3$ are presented in the Table 3. At this phase acceleration of the vehicle requires energy of ca $14 \mathrm{~kJ}$ to overcome air resistance, rolling and inertia resistance. At a constant speed a vehicle needs to consume the energy of $5 \mathrm{~kJ}$ to overcome air and rolling resistance and in deceleration to consume energy of $1.5 \mathrm{~kJ}$ to overcome only air and rolling resistance (Table 2).

The calculations of the $2 \mathrm{nd}$ and $3 \mathrm{rd}$ phases for Citroën C3 and for all three phases for Citroën C3 Hybrid Air were done in the same way. The results for Citroën C3 Hybrid Air are in the table 2.

The differences in the calculation of the required power and rolling and inertia resistance can be seen in Table 2. It is caused by changing vehicle weight and the coefficient of rolling resistance. Air resistance takes the same values.
In all three phases, the vehicle power is needed to overcome air, rolling and inertia resistance (Table 2) fixed on the path to achieve the desired speed to the urban driving cycle ECE 15.

Of course, vehicle needs more energy for acceleration, driving and deceleration. Some energy is lost in the transmission system. The total efficiency of transmission system of the vehicle with frontwheel drive is approximately $93 \%$ (Table 3 and 4).

Based on the previous calculations for the vehicle Citroën $\mathrm{C} 3$, part of the kinetic energy during the deceleration of the vehicle is consumed to overcome air resistance and rolling. The rest of the available energy is converting into the heat in braking. Hybrid vehicle Citroën C3 with Hybrid

\begin{tabular}{|c|c|c|c|c|c|c|c|c|c|}
\hline Cycle & Mode & Dist. [m] & $\mathrm{O}_{v}[\mathrm{~N}]$ & $\mathrm{O}_{f}[\mathrm{~N}]$ & $\mathrm{O}_{\mathrm{a}}[\mathrm{N}]$ & $E_{v}[J]$ & $E_{f}[\mathrm{~J}]$ & $\mathrm{E}_{\mathrm{a}}[\mathrm{J}]$ & $\mathrm{E}_{\mathrm{T}}[\mathrm{J}]$ \\
\hline \multirow{3}{*}{$\begin{array}{c}1 . \\
\text { phase }\end{array}$} & acceleration & 8,34 & 1,82 & 113,01 & 1651,32 & 15,18 & 942,50 & 13772,01 & 14729,69 \\
\hline & const. speed & 33,36 & 7,27 & 113,01 & 0,00 & 242,53 & 3770,01 & 0,00 & 4012,54 \\
\hline & deceleration & 10,43 & 1,82 & 113,01 & 1321,06 & 18,98 & 1178,69 & 13778,61 & $-12580,94$ \\
\hline \multirow{3}{*}{$\begin{array}{c}2 . \\
\text { phase }\end{array}$} & acceleration & 53,34 & 8,26 & 113,01 & 1173,48 & 440,59 & 6027,95 & 62593,42 & 69061,97 \\
\hline & const. speed & 213,36 & 33,02 & 113,01 & 0,00 & 7045,15 & 24111,81 & 0,00 & 31156,96 \\
\hline & deceleration & 48,9 & 8,26 & 113,01 & 1280,16 & 403,91 & 5526,19 & 62599,82 & $-56669,72$ \\
\hline \multirow{5}{*}{$\begin{array}{c}3 . \\
\text { phase }\end{array}$} & acceleration & 180,57 & 20,15 & 113,01 & 846,22 & 3638,49 & 20406,22 & 152802,22 & 176846,92 \\
\hline & const. speed & 166,68 & 81,61 & 113,01 & 0,00 & 13436,07 & 18836,51 & 0,00 & 32429,36 \\
\hline & deceleration & 90,81 & 20,15 & 113,01 & 825,66 & 1829,82 & 10262,44 & 74978,18 & $-62885,93$ \\
\hline & const. speed & 126,49 & 39,56 & 113,01 & 0,00 & 5003,94 & 14294,63 & 0,00 & 19298,58 \\
\hline & deceleration & 58,38 & 9,89 & 113,01 & 1284,36 & 577,38 & 6597,52 & 74980,94 & $-67806,03$ \\
\hline
\end{tabular}
Air system can store usable energy with efficiency $\eta=70 \%$. This energy is re-used during acceleration of the vehicle thereby reduce the energy

Table 2. The resulting values of driving resistance and energy for Citroën C3 Hybrid Air 
Table 3. Energy required for acceleration, deceleration at the desired speed for Citroën C3

\begin{tabular}{|l|c|c|c|c|}
\hline Cycle phase ECE 15 & 1. phase & 2. phase & \multicolumn{2}{|c|}{ 3. phase } \\
\hline Desired speed [km. $\mathrm{h}^{-1}$ ] & 15 & 32 & 50 & 35 \\
\hline Energy needed to acceleration [J] & 14132,91 & 66413,31 & 171878,45 & - \\
\hline $\begin{array}{l}\text { Energy needed to acceleration based on the total ef- } \\
\text { ficiency of transmission system (93\%) [J] }\end{array}$ & 15122,21 & 71062,90 & 183909,94 & - \\
\hline Energy for constant speed [J] & 5066,38 & 37897,00 & 37704,38 & 23294,40 \\
\hline $\begin{array}{l}\text { Energy for constant speed based on the total ef- } \\
\text { ficiency of transmission system (93\%) [J] }\end{array}$ & 5421,03 & 40549,79 & 40343,68 & 24925,00 \\
\hline Energy needed for deceleration [J] & 1527,16 & 7474,85 & 14960,95 & 8999,13 \\
\hline Usable energy [J] & 0 & 0 & 0 & 0 \\
\hline
\end{tabular}

Table 4. Energy required for acceleration, deceleration at the desired speed for Citroën C3 Hybrid Air

\begin{tabular}{|l|c|c|c|c|}
\hline Cycle phase ECE 15 & 1. phase & 2. phase & \multicolumn{2}{|c|}{ 3. phase } \\
\hline Desired speed [km. $\mathrm{h}^{-1}$ ] & 15 & 32 & 50 & 35 \\
\hline Energy required to acceleration [J] & 14729,69 & 69061,97 & 176846,92 & - \\
\hline $\begin{array}{l}\text { Energy required to acceleration based on the total ef- } \\
\text { ficiency of transmission system (93\%) [J] }\end{array}$ & 15760,77 & 73896,30 & 189226,20 & - \\
\hline Energy for constant speed [J] & 4012,54 & 31156,96 & 32429,36 & 19298,58 \\
\hline $\begin{array}{l}\text { Energy for constant speed based on the total efficiency } \\
\text { of transmission system (93\%) [J] }\end{array}$ & 4293,42 & 33337,95 & 34669,42 & 20649,82 \\
\hline Energy required for deceleration [J] & 1197,67 & 5930,10 & 12092,26 & 7174,90 \\
\hline Usable energy [J] & 12580,94 & 56669,72 & 62885,93 & 67806,03 \\
\hline
\end{tabular}

required to accelerate the vehicle to the desired speed $[5,6,8,9]$.

\section{USABLE ENERGY OF VEHICLE CITROËN C3 HYBRID AIR BY THE CYCLE ECE 15}

During the braking it is not possible to recover complete kinetic energy to the tank because part of the energy is consumed to overcome air resistance and rolling, some of the energy is consumed in transmission system. This feature is known as transmission losses. They are represented by value of the transmission system. Equations used for energy storage are under the Table 4.

Equation 11 has been used for the calculation of the recuperated energy amount $\mathrm{E}_{\mathrm{UX}}$ in the phase 1 . The same equation can be used for other phases of the driving cycle.

$$
\begin{gathered}
E_{U X}=E_{T X} \cdot \boldsymbol{\eta} \\
E_{U 1}=E_{T 1} \cdot \boldsymbol{\eta}=12580,94 \cdot 0,7=8806,66 \mathrm{~J}
\end{gathered}
$$

Total usable energy:

$$
E_{S}, E_{P}=\sum E_{U 1,2,3}
$$

where: $\mathrm{E}_{\mathrm{p}}$ - energy used for driving cycle by conventional Citroën $\mathrm{C} 3$,
$\mathrm{E}_{\mathrm{S}}$ - energy used for driving cycle by Citroën C3 Hybrid Air.

Calculation of percentage difference in the energy required for the cycle ECE 15 based on Table 5:

$$
R_{p}=\frac{E_{H A} \cdot 100}{E_{C 3}}=\frac{305,7,100}{414,3}=73,79 \%
$$

Based on previous calculations, it can be stated that the vehicle Citroën C3 with Hybrid Air system is capable of maintaining more than one quarter of the energy that would be otherwise converted into heat in braking, as it is in conventional vehicle with internal combustion engine. In the figure 5 and in the table 5 it can be seen the difference of needed energy to overcome driving resistance between the current car and vehicle with Hybrid Air system. The conventional vehicle needs to consume more energy than a vehicle with Hybrid Air system. It is mainly due to lower value of rolling resistance coefficient $[10,11]$.

\section{CONCLUSION}

The energy required to perform the cycle ECE 15 by using the vehicle with the hybrid air system is $26,2 \%$ lower than by using conventional vehicles Citroën C3. 


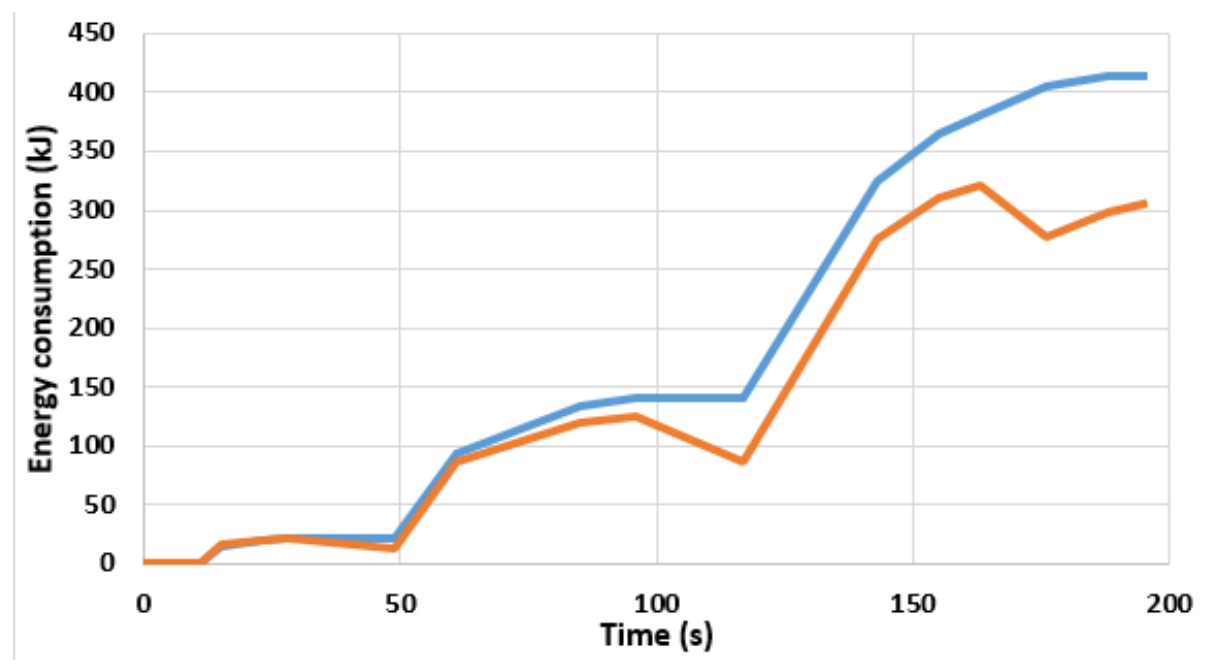

Fig. 5. Comparison of energy consumption of Citroën C3 and Citroën C3 Hybrid Air needed to perform the cycle ECE 15 based on Table 6

Table 5. Energy needed to perform the cycle ECE 15

\begin{tabular}{|c|c|c|c|c|}
\hline \multirow{2}{*}{ Time [s] } & \multicolumn{2}{|c|}{ Citroën C3 } & \multicolumn{2}{c|}{ Citroën C3 Hybrid Air } \\
\cline { 2 - 5 } & $\begin{array}{c}\text { Consumed overall energy } \\
\mathrm{E}_{\mathrm{C}}[\mathrm{kJ}]\end{array}$ & Energy increment [kJ] & $\begin{array}{c}\text { Consumed overall energy } \\
\mathrm{E}_{\mathrm{HA}}[\mathrm{kJ}]\end{array}$ & Energy increment [kJ] \\
\hline 0 & 0 & 0 & 0 & 0 \\
\hline 11 & 0 & 0 & 15,8 & 0 \\
\hline 15 & 15,1 & 15,1 & 20,1 & 15,8 \\
\hline 23 & 20,5 & 5,4 & 21,2 & 4,3 \\
\hline 28 & 22,1 & 1,5 & 12,4 & 1,2 \\
\hline 49 & 22,1 & 0 & 86,3 & $-8,8$ \\
\hline 61 & 93,1 & 71 & 119,6 & 33,9 \\
\hline 85 & 133,7 & 40,6 & 125,6 & 5,3 \\
\hline 96 & 141,2 & 7,5 & 85,9 & $-39,7$ \\
\hline 117 & 141,2 & 0 & 275,1 & 189,2 \\
\hline 143 & 325,1 & 183,9 & 309,8 & 34,7 \\
\hline 155 & 365 & 40,3 & 321,9 & 12,1 \\
\hline 163 & 380,4 & 15 & 277,9 & -44 \\
\hline 176 & 405,3 & 24,9 & 298,5 & 20,6 \\
\hline 188 & 414,3 & 9 & 305,7 & 7,2 \\
\hline 195 & 414,3 & 0 & & \\
\hline
\end{tabular}

If we assume that the path of the vehicle drive increases, the number of acceleration and deceleration increases as well and energy savings. The best use of the vehicle with the hybrid air system is in urban traffic at speeds up to $50 \mathrm{~km} \cdot \mathrm{h}^{-1}$, when the vehicle accelerates and decelerates repeatedly. The saving of energy and its re-use reduces consumption and also the production of harmful substances in the emissions of $\mathrm{CO}$, unburned hydrocarbons and $\mathrm{CO}_{2}$, which contributes to the greenhouse effect. Re-use of stored energy in the tanks also indirectly extends the life of the inter- nal combustion engine because during the use of stored energy the internal combustion engine is disconnected.

\section{REFERENCES}

1. Rievaj, V. et al.: Automobil a jeho dynamika. Žilina, 2013, EDIS, pp. 224.

2. PSA Groupe. Citroën C3 Hybrid Air, 2016, [online, cit. 3.04.2016]. Available on: http://www.psa-peugeot-citroen.com/en/content/citroen-c3-hybrid-air. 
3. Šarkan, B., Holeša, L.: Porovnanie globálne definovaných jazdných cyklov pre meranie emisií a spotreby pohonných látok. Doprava a Spoje. 2012, Vol. 8, No. 1.

4. Rajamani, R.: Vehicle dynamics and control. New York: Springer, 2012.

5. Wong, J., Y.: Theory of ground vehicles. Ottawa, John Wiley \& Sons. Inc., 2001.

6. Zuraulis V., Sokolovskij E., Matijosius J.: The opportunities for establishing the critical speed of the vehicle on research in its lateral dynamics. Eksploatacja i Niezawodnosc - Maintenance and Reliability, 2013, Vol. 15 (4), 312-318.

7. Caban J., Komsta H., Vrabel J.: Charakterystyka pojazdów samochodowych przeznaczonych do transportu paliw gazowych. In: TTS Technika transportu szynowego: koleje - tramwaje - metro, 2013.

8. Kucera, L., Gajdac, I., Mruzek, M.: Simulation of parameters influencing the electric vehicle range. Communications - scientific letters of UNIZA, 2016, Vol. 18, No. 1A, 59-63.

9. Caban, J. et al.: Studies on operational wear of glycol-based brake fluid. Przemysl Chemiczny. 2015, Vol. 94 (10), 1802-1806.
10. Rievaj, V., Mokrickova, L., Rievaj, J.: Impact of driving techniques on fuel consumption. Communications - Scientific Letters of UNIZA, 2016, Vol. 18 (2), 72-75.

11. Rievaj, V. et al.: The impact of air resistance on the fuel consumption in real conditions within the transport operation. Communications - Scientific Letters of UNIZA. Feb. 2016, Vol. 18 (2), 57-61.

12. Knez, M., Muneer, T., Jereb, B., Cullinane, K.: The estimation of a driving cycle for Celje and a comparison to other European cities. Sustainable Cities and Society, 2014, Vol. 11, 56-60.

13. Knez, M., Jereb, B., Obrecht, M.: Factors influencing the purchasing decisions of low emission cars: a study of Slovenia. Transportation Research. Part D, Transport and Environment. July 2014, Vol. 30, 53-61.

14. Figlus, T., Liscak, S.: Assessment of the vibroactivity level of SI engines in stationary and non-stationary operating conditions. Journal of Vibroengineering, May 2014, Vol. 16 (3), 1349-1359.

15. Figlus, T., Stanczyk, M.: Diagnosis of the wear of gears in the gearbox using the wavelet packet transform. In. Metalurgija, Oct-Dec 2014, Vol. 53, (4), 673-676. 